\title{
The first record of the pantropical millipede, Chondromorpha xanthotricha (Attems, 1898) (Diplopoda: Polydesmida: Paradoxosomatidae), from Thailand
}

\section{Первое сообщение о пантропической многоножкке-дипиоподе Chondromorpha xanthotricha (Attems, 1898) (Diplopoda: Polydesmida: Paradoxosomatidae) в Таиланде}

\author{
Natdanai Likhitrakarn ${ }^{1}$, Sergei I. Golovatch ${ }^{2}$, S. Panha ${ }^{3}$ \\ Н. Аихитракарн ${ }^{1}$, С.И. Головач ${ }^{2}$, С. Панха ${ }^{3}$
}

\footnotetext{
${ }^{1}$ Division of Plant Protection, Faculty of Agricultural Production, Maejo University, Chiang Mai 50290 Thailand. E-mail: kongerrrr@hotmail.com

${ }^{2}$ Institute for Problems of Ecology and Evolution, Russian Academy of Sciences, Leninsky pr. 33, Moscow 119071Russia. E-mail: sgolovatch@yandex.ru

${ }^{2}$ Институт проблем экологии и эволюции РАН, Ленинский проспект, 33, Москва 119071 Россия.

${ }^{3}$ Animal Systematics Research Unit, Department of Biology, Faculty of Science, Chulalongkorn University, Bangkok 10330 Thailand. Email: somsak.pan@chula.ac.th
}

KEY WORDS: Myriapoda, Sulciferini, anthropochore millipede, Chiang Mai.

КЛЮЧЕВЫЕ СЛОВА: Myriapoda, Sulciferini, антропохорная диплопода, Чьянг Маи.

ABSTRACT. The pantropical anthropochore millipede, Chondromorpha xanthotricha, is new to the fauna of both Chiang Mai Province and entire Thailand, collected in and around the city of Chiang Mai. It often occurred together with Orthomorpha coarctata, another pantropical introduced species, in such man-made habitats as coffee shop garden or compost heap. A detailed, richly illustrated description of C. xanthotricha is provided, based on the fresh samples from Thailand.

How to cite this article: Likhitrakarn N., Golovatch S.I., Panha S. 2017. The first record of the pantropical millipede, Chondromorpha xanthotricha (Attems, 1898) (Diplopoda: Polydesmida: Paradoxosomatidae), from Thailand // Arthropoda Selecta. Vol.26. No.4. P.281-287. doi: 10.15298/arthsel.26.4.01

РЕЗЮМЕ. Пантропическая антропохорная диплопода Chondromorpha xanthotricha - новая для фаун как провинции Чьянг Маи, так и всего Таиланда. Она была собрана как в самом городе Чьянг Маи, так и в его окрестностях, притом часто вместе с видом Orthomorpha coarctata, еще одним пантропическим интродуцентом, в саду кафетерия и куче компоста. Представлено детальное, обильно иллюстрированное описание C. xanthotricha на основе нового материала из Таиланда.

\section{Introduction}

Chondromorpha xanthotricha (Attems, 1898) is a pantropical anthropochore millipede which, together with its several synonyms and/or subspecies, occurs in synanthropic habitats in the Mascarene Islands, India, Sri Lanka, Singapore, Indonesia, Taiwan, Oceania, Fiji Islands, Samoa, the Philippines, New Guinea, United States, Mexico, Costa Rica, Panama, the Greater and Lesser Antilles, Venezuela etc. [Shelley, Lehtinen, 1998; Shelley, Cupul-Magaña, 2007; Decker, Tertilt, 2012; Nguyen, Sierwald, 2013]. The origin centre is presumed to have lain in Sri Lanka or southern India [e.g. Nguyen, Sierwald, 2013].

Thailand is located within both the Indo-Burma and Sundaland biodiversity mega-hotspots identified by Myers et al. [2000] as globally significant. The diplopod species diversity in Thailand has hitherto been reported to total 195 species [Enghoff, 2005; Likhitrakarn et al., 2015a, b, 2016; Pimvichai et al., 2016; Srisonchai et al., 2016]. Among them, only seven species are particularly widespread, mostly as a result of anthropochory [Enghoff, 2005; Decker, 2010]: Nepalmatoiulus birmanicus (Pocock, 1893), Pseudospirobolellus avernus (Butler, 1876), Trigoniulus corallinus (Gervais, 1847), Trachyjulus calvus (Pocock, 1893), Hypocambala helleri Silvestri, 1897, Leptogoniulus sorornus (Butler, 1876) and Orthomorpha coarctata (DeSaussure, 1860). The latter species has hitherto remained the only pantropical representative of the order Polydesmida to be reported from Thailand [Enghoff, 2005]. Jeekel [1972] assumed that O. coarctata might have originated in an area lying between Indochina and Java. Based on a recent revision of the entire genus Orthomorpha Bollman, 1893, which presently contains $>50$ species [Likhitrakarn et al., 2011], the origin area $O$. coarctata has since hardly been precised 
as having been located somewhere in the mainland of Southeast Asia.

The present paper puts on record Chondromorpha xanthotricha, surprisingly only a second genus and species of pantropical Paradoxosomatidae and Polydesmida to be found in Thailand. We also take the opportunity to redescribe and properly illustrate this species, as well as provide more insights into its biology.

\section{Material and methods}

New material was collected from Chiang Mai, Thailand from 2014 to 2017. Live animals and their habitats were photographed in the field. Specimens were preserved in $75 \%$ ethanol, and morphological investigations were carried out in the laboratory using an Olympus stereo microscope. Scanning electron micrographs (SEM) of gonopods coated with gold were taken with the aid of a JEOL, JSM-5410 LV microscope, and returned to alcohol after examination to ultimately be stored in the alcohol collection. Digital images of the specimens were taken in the laboratory and assembled using the "Cell ${ }^{D}$ " automontage software of the Olympus Soft Imaging Solution $\mathrm{GmbH}$ package. In addition, line drawings of gonopods were also prepared. All specimens are kept in the Museum of Zoology, Chulalongkorn University, Bangkok, Thailand. Collecting sites were located by GPS using the WGS84 datum.

\section{Results}

\section{Chondromorpha xanthotricha (Attems, 1898)} Figs 1-4.

MATERIAL. $6 \bigcirc^{7} \sigma^{7}, 4$ 우, Thailand, Chiang Mai Province, San Sai District, Maejo University, on a compost heap under Ficus benjamina L., $320 \mathrm{~m}$ a.s.1., $18^{\circ} 53^{\prime} 40^{\prime \prime} \mathrm{N}, 9^{\circ} 01^{\prime} 02^{\prime \prime} \mathrm{E}, 28.07 .2014$ $1 \mathrm{O}^{\top}$, same locality, 3.08.2015; $1 \mathrm{O}^{\top}, 1$ \%, same locality, 8.09.2016; 1 , same District, Baan Nonnipa Village, 311 m a.s.1., $18^{\circ} 53^{\prime} 21^{\prime \prime} \mathrm{N}$, 98 $8^{\circ} 59^{\prime} 57^{\prime \prime} \mathrm{E}, 8.09 .2016 ; 4 \mathrm{O}^{7} \mathrm{O}^{7}, 5$ 우, same District, under tree fence (Ficus annulata Blume \& Ehretia microphylla Lam.) in front of a coffee shop, $311 \mathrm{~m}$ a.s.1., $18^{\circ} 49^{\prime} 40^{\prime \prime} \mathrm{N}, 99^{\circ} 00^{\prime} 45^{\prime \prime} \mathrm{E}, 1.09 .2014$, all leg. N. Likhitrakarn; $6 \bigcirc^{7} \sigma^{7}, 8$ 우, 1 juv., same District, $H$ Apartment Maejo, under tree fence (Wrightia religiosa (Teijsm. \& Binn.) Kurz) in front of apartment, $319 \mathrm{~m}$ a.s.1., $18^{\circ} 53^{\prime} 13^{\prime \prime} \mathrm{N}$, $99^{\circ}$ 01'44"E, 10.07.2017, leg. T. Kumpliw; 6 O $^{7} \sigma^{7}, 9$ 우, 9 juv., Mae Rim District, Queen Sirikit Botanic Garden, 795 m a.s.1., 18 ${ }^{\circ} 3^{\prime}$ $16^{\prime \prime} \mathrm{N}, 98^{\circ} 51^{\prime} 31^{\prime \prime} \mathrm{E}, 9.02 .2016$, leg. R. Saokhot.

REDESCRIPTION. Length mostly 13.8-18.0 $\left(\sigma^{7}\right)$ or $16.2-19.3 \mathrm{~mm}\left({ }_{+}\right)$, width of midbody pro- and metazonae $1.1-1.4$ and $1.6-1.9 \mathrm{~mm}\left(\sigma^{7}\right)$ or $1.4-1.8$ and $1.8-2.4 \mathrm{~mm}(+)$, respectively.

Coloration of live animals blackish (Fig. 1A) with a pattern of posterior halves of paraterga contrasting yellow, head and antennae blackish to dark brown, legs and venter light brown to pale yellow; coloration in alcohol faded after three months of preservation, paraterga faded to light yellow, venter and a few basal podomeres light brown to pallid, legs increasingly infuscate (brown) distally (Fig. 1B-J).
Clypeolabral region and vertex sparsely setose, epicranial suture distinct. Antennae moderately long (Fig. $1 \mathrm{~A}, \mathrm{~B} \& \mathrm{C})$, reaching body segment $3\left(\mathrm{O}^{7},+\right)$ when stretched dorsally. In width, head $<$ segment $4<$ collum $<$ segment $3<5<2<6-17\left(\sigma^{7}\right.$,, ) , thereafter body gently and gradually tapering. Collum with three transverse rows of setiferous cones: $6+6$ anterior, $5+5$ intermediate and $5+5$ posterior; a small incision laterally in posterior half; caudal corner of paraterga broadly rounded, slightly declined ventrad, produced behind rear tergal margin (Fig. 1B \& C).

Tegument mostly rough, but shining, prozonae very finely shagreened, metaterga roughly microgranulate, granulate and shagreened; surface below paraterga roughly microgranulate. Metaterga 2-14 with three transverse rows of setiferous cones: $5(6)+5(6)$ anterior, $4(5)+4(5)$ intermediate and $5(4)+5(4)$ posterior. Metaterga 15-19 with $6(7)+6(7)$ setae in anterior, $5(6)+5(6)$ in intermediate and $6-8+6-8$ posterior rows, also borne on cones (Fig. 1B, D \& F). Tergal setae long, strong, slender, about $1 / 3$ of metatergal length. Axial line traceable on both pro- and metaterga.

Paraterga very strongly developed (Fig. 1B-F \& $\mathrm{H})$, set at about $1 / 5$ midbody height, slightly upturned, all lying very high, but always below dorsum; shoulders rather well developed, mostly rounded and narrowly bordered, fused to callus; caudal corner almost completely to fully pointed, extending increasingly behind tergal margin, posterior edge mostly oblique, especially strongly so on segments 17-19 (Fig. 1F); paraterga very thin blunt blades in lateral view, a little thicker only in pore-bearing segments. Calluses on paraterga delimited by a sulcus both dorsally and ventrally. Paraterga 2-4 with two lateral marginal incisions in anterior $1 / 3$, one evident, the other small; posterior edge concave (Fig. 1B). Lateral edge of following segments with evident incisions, one in anterior $1 / 3$, the other at midway; posterior edge concave with a few small crests at base of paraterga (Fig. 1B). Ozopores evident, lateral, lying in a long ovoid groove at about $1 / 4$ in front of caudal corner. Transverse sulcus usually distinct (Fig. 1B, D \& F), slightly incomplete on segments 3 and 19, complete on metaterga 4-18, narrow, wavy and shallow, reaching bases of paraterga, ribbed at bottom. Stricture between pro- and metazonae very wide, rather deep, slightly ribbed at bottom down to base of paraterga (Fig. 1B-E). Pleurosternal carinae complete crests with a sharp caudal tooth only on segment 2, a small front tooth on segment 3, thereafter missing $\left(\sigma^{7},+\right)$ (Fig. 1C, E \& H). Epiproct (Fig. $1 \mathrm{~F} \& \mathrm{H}$ ) conical, flattened dorsoventrally, apical papillae absent; tip subtruncate; pre-apical papillae small, but evident, lying close to tip. Hypoproct roundly subtrapeziform (Fig. 1G), setiferous knobs at caudal edge well-separated and evident.

Sterna sparsely setose, without modifications except for a large and setose lobe bearing a paramedian pair of cones between $\sigma^{7}$ coxae 4 (Fig. 1 I \& J). Legs very long and slender, midbody ones ca $1.3-1.4\left(\sigma^{7}\right)$ or 


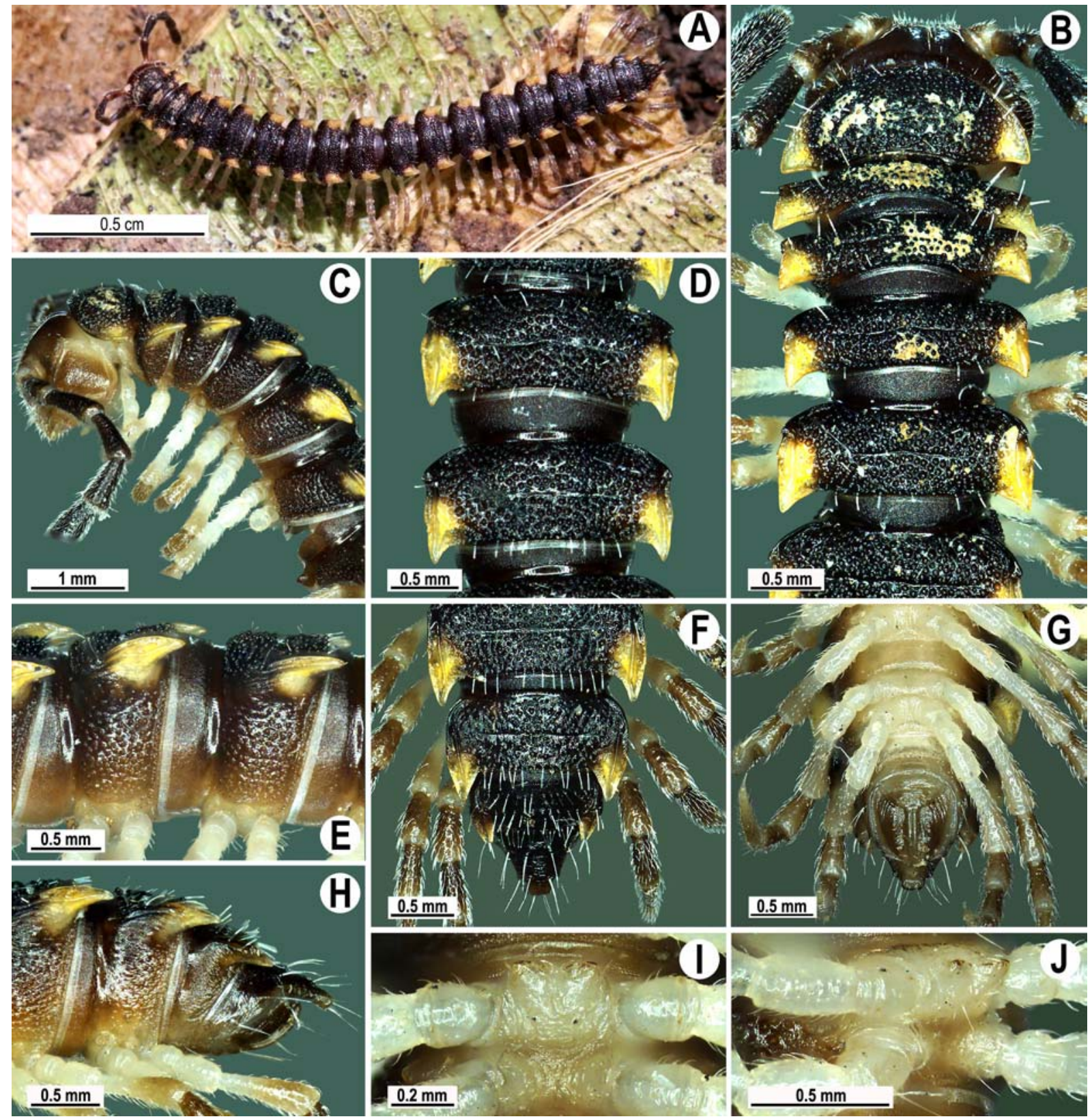

Fig. 1. Chondromorpha xanthotricha (Attems, 1898), $\mathrm{O}^{7}: \mathrm{A}$ - habitus, live coloration; B, C - anterior part of body, dorsal and lateral views, respectively; D, E - segments 10 and 11, dorsal and lateral views, respectively; F-H - posterior part of body, dorsal, ventral and lateral views, respectively; I, J - sternal cones between coxae 4, ventral and ventrolateral views, respectively.

Рис. 1. Chondromorpha xanthotricha (Attems, 1898), ○’: А - общий вид, прижизненная окраска; В, С - передняя часть тела, соответственно сверху и сбоку; D, E - сегменты 10 и 11, соответственно сверху и сбоку; F-H - задняя часть тела, соответственно сверху, снизу и сбоку; I, J - стернальные конусы между коксами 4, соответственно снизу и одновременно снизу и сбоку.

1.1-1.2 times ( $(+)$ as long as body height (Fig. 1A \& C); prefemora without modifications, tarsal brushes absent.

Gonopods (Figs $2 \& 3$ ) rather simple; coxa curved caudad, sparsely setose distoventrally. Prefemur as usual, densely setose, about $1 / 3$ as long as femorite + postfemoral part. Femorite rather stout, with an evident distolateral sulcus demarcating femorite from postfemoral part; the latter well-developed, with only one mesal, tongue-shaped, basal process (b) and an evident apicoventral shelf (as); solenophore ( $\mathbf{s p h}$ ) consisting mainly of a large, conspicuous, slightly trifid lamina medialis supporting a long flagelliform solenomere (sl).

REMARKS. The first material was collected from a compost heap under Ficus benjamina within the Maejo University campus near a lecture building. The habitat was clearly man-made. Superficially, that sample of $C$. xanthotricha looked very similar to Orthomorpha coarctata (Fig. 4), a pantropical species that is very com- 


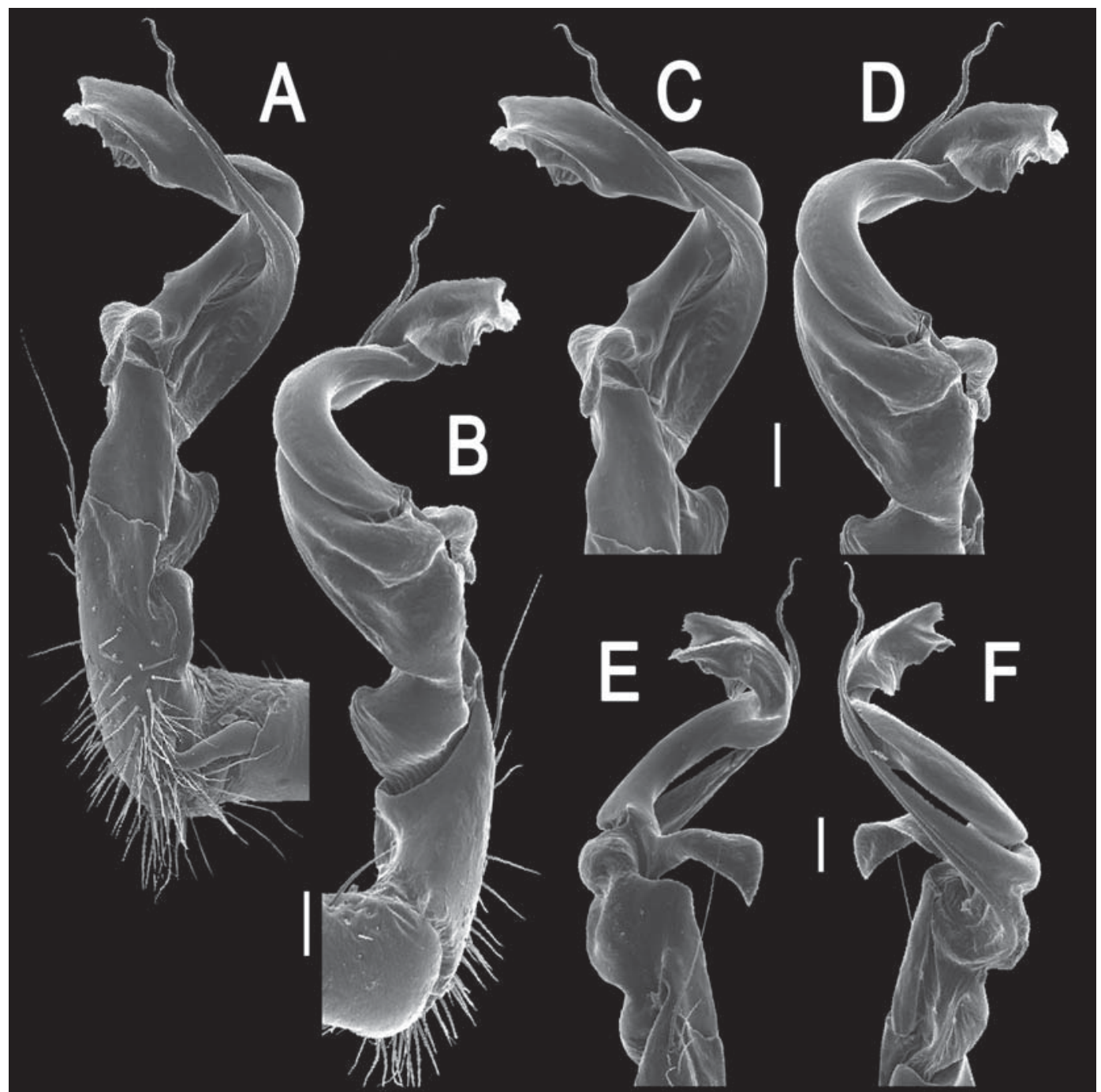

Fig. 2. Chondromorpha xanthotricha (Attems, 1898), $\mathrm{O}^{7}$ : A-F — right gonopod, A, B — mesal and lateral views, respectively; C-F — distal part, mesal, lateral, subfrontal and subcaudal views, respectively. Scale bar: $0.1 \mathrm{~mm}$.

Рис. 2. Chondromorpha xanthotricha (Attems, 1898), О: A-F - правый гонопод, А, В - соответственно изнутри и сбоку; С-F дистальная часть, соответственно изнутри, сбоку, примерно спереди и примерно сзади. Масштаб: 0,1 мм.

mon throughout Southeast Asia [Likhitrakarn et al., 2011] (Fig. 4A) and, at least at and near Chiang Mai, co-occurs not only sympatrically, but often also syntopically with $C$. xanthotricha. Furthermore, the latter species usually appears in mass numbers (close to outbreaks) every year, but only during the rainy season (July to September), to quickly disappear thereafter. The only exception was the population from Queen Sirikit Botanic Garden, outside the city, which seems to be less strongly seasonal. Typically, C. xanthotricha animals are quite active and move more quickly around the urban area, at least so compared to O. coarctata.

\section{Discussion}

Since 2006, O. coarctata has been collected throughout Thailand [Likhitrakarn et al., 2011], including the city of Chiang Mai in northern Thailand. However, the earliest record of this species in the country actually dates back to the end of the $19^{\text {th }}$ century, when Daday [1889] described it as a new species (under the name Paradesmus flavocarinatus Daday, 1889, synonymized by Enghoff [2005]) from Bangkok. In contrast, Chondromorpha xanthotricha was first discovered in 2014 together with $O$. coarctata, both observed as sharing the same places within the Maejo University campus and other synanthropic habitats. Likewise coexisting populations of both species are known to occur on several Pacific tropical archipelagos and found in similar environments [Shelley, Lehtinen, 1998]. Among these, 19 islands were noted to support $O$. coarctata, including only five islands with coexisting $C$. xanthotricha.

Two years later, the population of $O$. coarctata in the Maejo University area was observed as having 


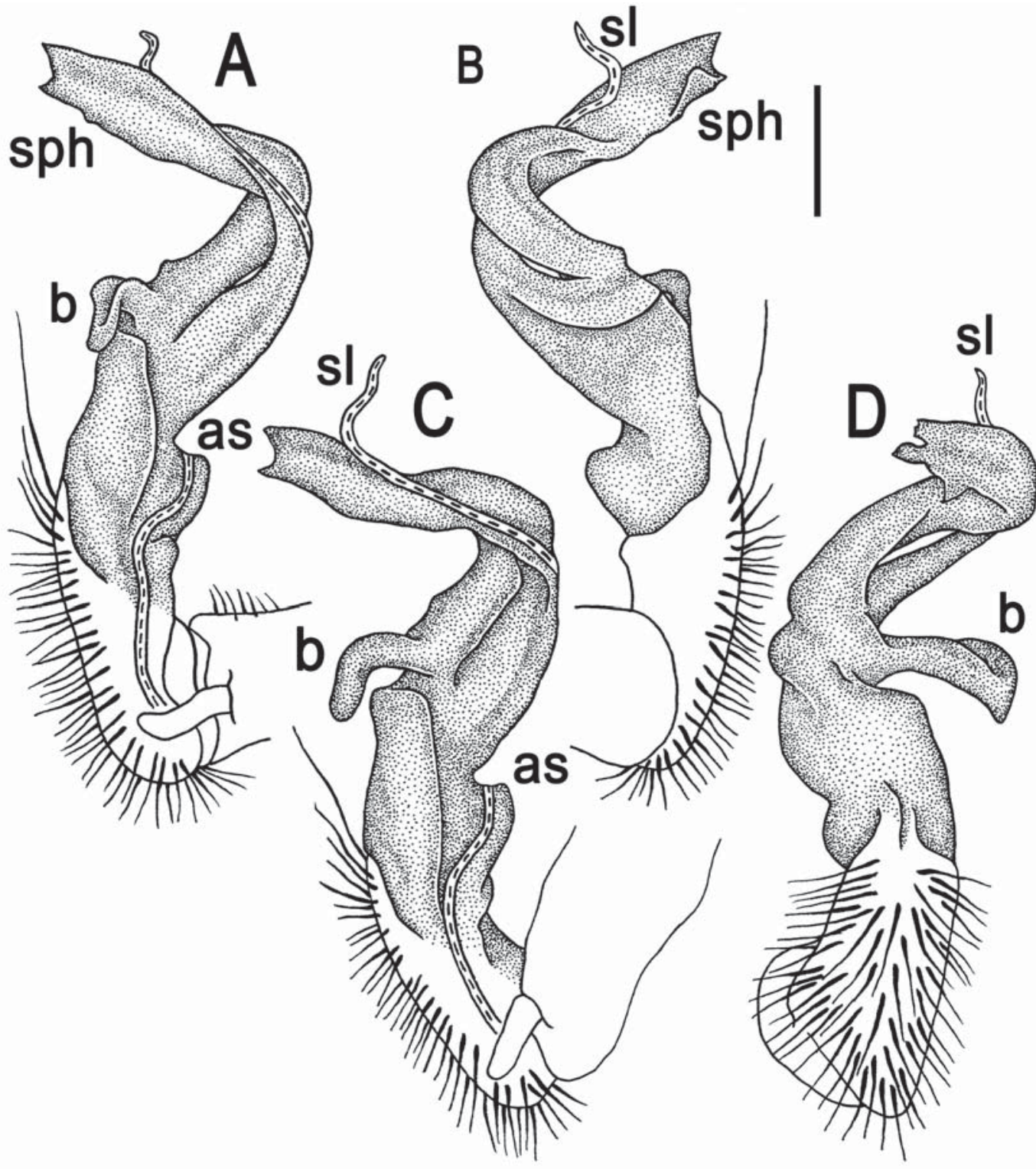

sph

Fig. 3. Chondromorpha xanthotricha (Attems, 1898), o': A-D — right gonopod, mesal, submesal, sublateral and subfrontal views, respectively. Scale bar: $0.2 \mathrm{~mm}$. Designations explained in text.

Рис. 3. Chondromorpha xanthotricha (Attems, 1898), O’: A-D - правый гонопод, соответственно изнутри, почти изнутри, примерно сбоку и примерно спереди. Масштаб: 0,2 мм. Обозначения объяснены в тексте.

decreased, whereas that of C. xanthotricha increased, especially in places like compost heap, coffee shop, $\mathrm{H}$ Apartment Maejo where $O$. coarctata was no longer revealed.

More recently, in 2016, both species were taken in the Queen Sirikit Botanic Garden, where C. xanthotricha catches amounted to 24 individuals $\left(6 O^{7} \sigma^{7}, 9\right.$ 0 , 9 juveniles), i.e. $80 \%$ of the total collection, versus only six $O$. coarctata $\left(2 \sigma^{\top} \sigma^{\top}, 1+3\right.$ juveniles, or $20 \%$ ). We thus suggest that the presence of more recently introduced $C$. xanthotricha populations may have an effect on $O$. coarctata in the same area. Further studies must focus on their biology, life history and ecology, especially in places of their co-occurrence and possible interaction.

Above is the first formal record of both Chondromorpha and C. xanthotricha from the Chiang Mai Province and generally from Thailand.

ACKNOWLEDGEMENTS. This project was partly funded through grants received from the Office of the Royal Development Projects Board (RDPB), while most of the financial support was obtained from The Thailand Research Fund, The TRF Senior Research Scholar RTA 5880002 (2015-2018) to SP. We are grateful to Dr. Kamonnate Srithi for helping us in the 


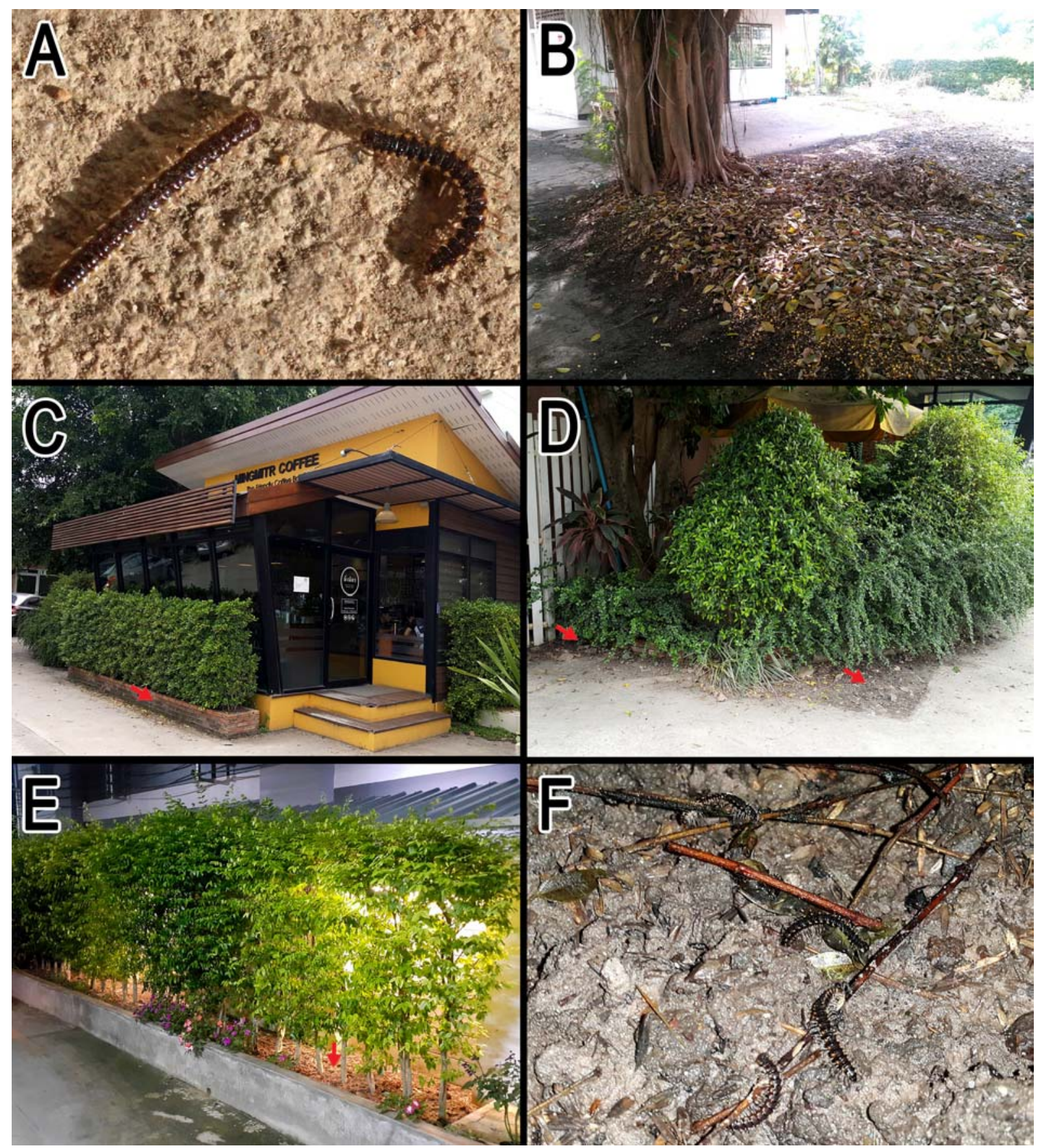

Fig. 4. Live Orthomorpha coarctata (DeSaussure, 1860) and Chondromorpha xanthotricha (Attems, 1898) and their joint habitats. A habitus, live colorations of $O$. coarctata (left) and $C$. xanthotricha (right); B — compost heap under Ficus benjamina; C, D - tree fences (Ficus annulata \& Ehretia microphylla) near coffee shop; E - tree fence (Wrightia religiosa) in front of H Apartment Maejo; F habitus, live coloration of C. xanthotricha.

Рис. 4. Живые coarctata (DeSaussure, 1860) и Chondromorpha xanthotricha (Attems, 1898) и их совместные биотопы. А общий вид, прижизненная окраска O. coarctata (слева) и C. xanthotricha (справа); В — компостная куча под Ficus benjamina; C, D — ограды из деревьев (Ficus annulata \& Ehretia microphylla) около кофейни; Е — ограда из деревьев (Wrightia religiosa) перед H Apartment Maejo; F - общий вид, прижизненная окраска C. xanthotricha. 
identification of plants. We also thank the members of the Animal Systematics Research Unit for their invaluable assistance.

\section{References}

Daday J. 1889. Myriopoda extranea Musaei Nationalis Hungarici // Természetrajzi Füzetek. T.12. No.4. P.115-156.

Decker P. 2010. Contributions to the myriapod fauna of ThailandNew records of millipedes and centipedes from Thailand (Myriapoda: Diplopoda, Chilopoda) // Schubartiana. Nr.4. S.23-34.

Decker P., Tertilt T. 2012. First records of two introduced millipedes Anoplodesmus saussurii and Chondromorpha xanthotricha (Diplopoda: Polydesmida: Paradoxosomatidae) in Singapore // Nature in Singapore. Vol.5. P.141-149.

Enghoff H. 2005. The millipedes of Thailand (Diplopoda) // Steenstrupia. Vol.29. No.1. P.87-103.

Jeekel C.A.W. 1972. The "endemic" paradoxosomatids (Diplopoda, Polydesmida) of the Fiji Islands // Beaufortia. Vol.20. No.258. P.1-6.

Likhitrakarn N., Golovatch S.I., Panha S. 2011. Revision of the Southeast Asian millipede genus Orthomorpha Bollman, 1893, with the proposal of a new genus (Diplopoda, Polydesmida, Paradoxosomatidae) // ZooKeys. Vol.131. P.1-161. https:// doi.org/10.3897/zookeys.131.1921

Likhitrakarn N., Golovatch S.I., Panha S. 2015a. A checklist of the millipedes (Diplopoda) of Cambodia // Zootaxa. Vol.3973. No.1. P.175-184. http://dx.doi.org/10.11646/zootaxa.3973.1.7

Likhitrakarn N., Golovatch S.I., Panha S. 2015b. Three new species of the pill millipede genus Hyleoglomeris Verhoeff, 1910, from northern Thailand (Diplopoda, Glomerida, Glomeridae) // Zootaxa. Vol.4044. No.1. P.130-140. https://doi.org/10.11646/ zootaxa.4044.1.7
Likhitrakarn N., Golovatch S.I., Panha S. 2016. The millipede genus Tylopus Jeekel, 1968 (Diplopoda, Polydesmida, Paradoxosomatidae), with a key and descriptions of eight new species from Indochina // European Journal of Taxonomy. No.195. P.1-47. http://dx.doi.org/10.5852/ejt.2016.195

Myers N., Mittermeier R.A., Mittermeier C.G., da Fonseca G.A.B., Kent J. 2000. Biodiversity hotspots for conservation priorities // Nature. Vol.403. P.853-858.

Nguyen A.D., Sierwald P. 2013. A worldwide catalog of the family Paradoxosomatidae Daday, 1889 (Diplopoda: Polydesmida) // Check List. Vol.9. No.6. P.1132-1353. http://dx.doi.org/ 10.15560/9.6.1132

Pimvichai P., Enghoff H., Panha S., Backeljau T. 2016. A revision of the Thyropygus allevatus group. Part V: Nine new species of the extended opinatus subgroup, based on morphological and DNA sequence data (Diplopoda: Spirostreptida: Harpagophoridae) // European Journal of Taxonomy. No.199. P.1-37. http://dx.doi.org/10.5852/ejt.2016.199

Shelley R.M., Cupul-Magaña F.G. 2007. Occurrences of the milliped, Chondromorpha xanthotricha (Attems, 1898), in the New World: first records from Mexico, Costa Rica, Panama, the Cayman Islands, Saint Vincent and The Grenadines, and Tobago; first localities in Cuba (Polydesmida: Paradoxosomatidae) // Entomological News. Vol.118. No.2. P.213-216.

Shelley R.M., Lehtinen P.T. 1998. Introduced millipeds of the family Paradoxosomatidae on Pacific Islands (Diplopoda: Polydesmida) // Arthropoda Selecta. Vol.7. No.2. P.81-94.

Srisonchai R., Enghoff H., Likhitrakarn N., Panha S. 2016. Four colorful new species of dragon millipedes, genus Desmoxytes Chamberlin, 1923, from northern Thailand (Diplopoda: Polydesmida: Paradoxosomatidae)//Zootaxa. Vol.4170. No.1. P.93113. http://www.mapress.com/j/zt/

Responsible editor K.G. Mikhailov 